Egyptian Journal of Aquatic Biology \& Fisheries

Zoology Department, Faculty of Science,

Ain Shams University, Cairo, Egypt.

ISSN $1110-6131$

Vol. 23(3): 455 - 465 (2019)

www.ejabf.journals.ekb.eg

\title{
Removal of ammonia and orthophosphate from domestic wastewater using marine actinomycetes
}

\author{
Amany G. Madkour*, Moaz M. Hamed and Mahmoud A. Dar \\ National Institute of Oceanography and Fisheries, Egypt \\ *Corresponding author: dramanymadkour@yahoo.com
}

\section{ARTICLE INFO \\ Article History: \\ Received: May22, 2019 \\ Accepted: Aug. 29, 2019 \\ Online: Sept. 2019}

\section{Keywords:}

Removing efficiency

Actinomycetes

Ammonia

Orthophosphates

Domestic wastewaters

\begin{abstract}
The present study aims to experiment the efficiency of marine actinomycetes in ammonia and orthophosphates removing from domestic wastewaters collected from El-Gona Wastewater Treatment Station, Hurghada, Red Sea. Ten marine actinomycets isolates were isolated from sediments in the Suez Gulf and identified as: Kocuria palustris, Streptomyces parvus, Streptomyces griseorubens, Streptomyces rochei, Streptomyces albidoflavus, Streptomyces griseus and four belonged to Streptomyces sp based on their 16S rRNA gene sequence analysis. The results demonstrated that, the experimented actinomycetes have differential effectiveness in the domestic wastewater treatment and have significant abilities to remove ammonia and orthophosphates. Streptomyces griseorubens and Streptomyces griseus are more efficient organisms in ammonia and orthophosphates removal $(77.35,79.02 \%$, respectively) from the raw wastewater relative to the other strains.
\end{abstract}

\section{INTRODUCTION}

The shortage of freshwater resources has become a globally serious problem where the growing population, advanced agricultural practices, industrialization, urbanization and the multiple uses of freshwater have increased the demand for freshwater. Sewage after appropriate treatment and the reuse of the recycled wastewater have become the consensus solution all-over the world (Qin et al. 2013).

Actinomycetes have many benefits as a wastewater treatment tool for many purposes ; first, they can use several growth substrates ranging from sugars to polysaccharides, proteins and aromatic compounds of elevated molecular weight (Lemmer and Kroppensted, 1984; Lemmer, 1986), secondly the high resistances of these actinomycetes to desiccation and ultraviolet irradiation and thirdly, their storage capacity for polyphosphates and poly- $\beta$-hydroxybutyric acid (Lemmer and Baumann, 1988)

Actinomycetes have recently become the focus of studies in activated sludge and sewage because they are thought to play a significant part in activated sludge bulking and foaming. (Davenport et al. 2000; Madoni et al. 2000; Heard et al. 2008).

Nitrogen and phosphorus removal from the wastewater is the main purpose for the wastewater treatment. Nitrogen is removed by energy and time consuming procedure, which is based on the combination of anaerobic or anoxic denitrification and autotrophic nitrification (Khardenavis et al. 2007; Khin and Annachhatre, 2004). 
Denitrification is known to proceed as conversion of nitrates to nitrites and subsequent conversion of nitrites to nitric oxide, nitrous oxide and nitrogen gas. Nitrogen appears in wastewater as; ammonia, nitrite, nitrate and organic nitrogen. Part of the organic nitrogen is decomposed to ammonia, which is assimilated to the bacterial cells leading to growth and the other part is oxidized to nitrite and nitrate. Latterly, nitrate is converted to gaseous nitrogen and then removed from the wastewater.

Phosphorus in wastewater was found as orthophosphate, polyphosphate and organic phosphorus, the last two components representing up to $70 \%$ of the influent phosphorus. Microbes utilize phosphorus during cell synthesis and energy transport. About $10 \%$ to $30 \%$ of the influent phosphorus was found to be removed during traditional mechanical and biological treatments (Wenzel and Ekama, 1997; Mulder and Rensink, 1987; Metcalf and Eddy, 1991; Henze, 1996; Sedlak, 1991).

The aim of the present study to experiment the efficiency of actinomycetes in ammonia and orthophosphates removing from domestic wastewaters collected from El-Gona Wastewater Treatment Station, Hurghada, Red Sea.

\section{MATERIALS AND METHODS}

\section{Sampling of isolated actinomycetes}

Sediments samples were collected according to (Norouzi et al. 2018) from four sites along Suez gulf, Egypt using piston corer in clean plastic bags. The samples were immediately transported for bacteriological analysis to the laboratory in an ice box that was always completed within 24 hours.

\section{Isolation of actinomycetes}

Approximately $5 \mathrm{~g}$ of each sediment sample was added to $15 \mathrm{ml}$ of sterilized seawater, then shacked for $25 \mathrm{~min}$ and thermally treated to decrease the amount of non-cell bacteria in favor of actinomycetes. Starch nitrate agar medium plates (Starch, 20; $\mathrm{KNO}_{3}, 1 ; \mathrm{K}_{2} \mathrm{HPO}_{4}, 0.5 ; \mathrm{MgSO}_{4} .7 \mathrm{H}_{2} \mathrm{O}, 0.5 ; \mathrm{FeSO}_{4} .7 \mathrm{H}_{2} \mathrm{O}, 0.01$; agar 20) were inoculated with $1 \mathrm{ml}$ of the samples (Mohanraj and Sekar, 2013). To minimize fungal contamination, the media was supplemented with 75 and $25 \mathrm{ug}$ ml-1 filter sterilized cycloheximide and nystatin (Shrivastava et al. 2015). 10 isolates were selected from the plates after incubation and repeatedly streaked to the same medium to obtain pure cultures. The pure isolates were preserved in $20 \%$ glycerol at $-20^{\circ} \mathrm{C}$ as inventory suspensions. Then 10 isolates were identified as morphologically distinct as; M5, M8, M9, M13, M15, M23, M38, M50, MN and MP then were used for morphological and biochemical identifications.

\section{Morphological and physiological characteristics of isolated actinomycetes:}

The chosen prospective actinomycetes isolates have been explored according to morphological, cultural, physiological and biochemical properties (Bensultana et al. 2010). Under light microscope, the color of the spore mass was examined and estimated by color chart. Cultural characteristics of actinomycetes isolates were examined by the eye of 14-day-old culture grown on Starch nitrate agar media. The inclined cover slip technique on starch casein agar after 7 days of incubating at $30^{\circ} \mathrm{C}$ observed micro morphology and sporulation under a light microscope. Eyes examined the colors of aerial and substratum mycelia ( $\mathrm{Li}$ et al. 2016). Unless otherwise specified, all physiological tests were performed at $30^{\circ} \mathrm{C}$ and $\mathrm{pH}$ 7.0. The efficacy of different temperatures and $\mathrm{pH}$ conditions on growth and tolerance of actinomycetes isolates to salt was determined by the use of plates produced with altered starch nitrate agar medium (Akond et al. 2016). Utilization of carbon source 
(Starch, Lactose, Dextrose, Maltose, glucose, and Glycerol) was examined using mineral salts agar medium containing $\mathrm{gl}^{-1}:\left(\mathrm{NH}_{4}\right)_{2} \mathrm{SO}_{4}, 2.64 ; \mathrm{KH}_{2} \mathrm{PO}_{4}, 2.38$; $\mathrm{K}_{2} \mathrm{HPO}_{4} .3 \mathrm{H}_{2} \mathrm{O}, 5.65 ; \mathrm{MgSO}_{4} .7 \mathrm{H}_{2} \mathrm{O}, 1$ and agar, $15, \mathrm{pH}$ adjusted to 7.0. Various biochemical tests performed for the identification of the actinomycetes isolates are as follows: production of Protease, Lipase, Urease, Catalase, Chitinase, Oxidase, Sulphide production and Melanin production (Yu et al. 2015).

\section{DNA extraction and 16S rRNA sequencing}

The molecular identification of the isolates used was carried out by extracting genomic DNA using the Gene Jet genomic DNA purification kit (Fermentas) genomic DNA extraction protocol. Using Maxima Hot Start PCR Master Mix (Fermentas) Polymerase Chain Reaction (PCR) was used. The PCR thermocycler was programmed as follows: $95^{\circ} \mathrm{C}$ for initial denaturation for $5 \mathrm{~min}, 30$ cycles for $1 \mathrm{~min}$ at $95^{\circ} \mathrm{C}, 55^{\circ} \mathrm{C}$ for $1 \mathrm{~min}, 72^{\circ} \mathrm{C}$ for $2 \mathrm{~min}$ and a final extension for $10 \mathrm{~min}$ at $72^{\circ}$ C. The PCR mixture contained 25 pmol of each primer, $10 \mathrm{ng}$ chromosomal DNA, $200 \mathrm{mmol} / \mathrm{LdNTPs}$ and $2.5 \mathrm{U}$ of Taq Polymerase in $50 \mu \mathrm{L}$ of Taq polymerase buffer 10X Standard Taq Reaction Buffer. The PCR Clean-Up of the PCR product was performed using Gene JETTM PCR Purification Kit (Fermentas) at "Sigma Scientific Services Company, Egypt". The GATC Company used ABI 3730xl DNA sequencer with universal primers to sequence the PCR product (16S 27F and 16S 1492R), (5'AGAGTTTGATCCTGGCTCAG-3' and 5'-GGTTACCTTGTTACGACTT-3'). Genotypical characterization was carried out using sequence analysis of $16 \mathrm{~S}$. For comparison, sequences of rRNA genes were obtained from the database of the National Biotechnology Information Center (NCBI).

\section{Effect of the actinomycete isolates on removal of ammonia and phosphate from the wastewater}

The raw wastewater samples were collected from El Gona wastewater station on the northern Egyptian Red Sea coast. The samples were filtered through $45 \mu$ filter membrane to remove the suspended particles and any materials $(\geq 45 \mu)$, then sterilized in the autoclave at $121^{\circ} \mathrm{C}$ for 20 minutes to avoid any contaminations by the microbial organisms (fungal and bacterial). Physical parameter ( $\mathrm{pH}$, TDS Dissolved oxygen and salinity) were measured using Inst. Model (YSI 5913). The dissolved ammonia and orthophosphates in the wastewater were measured using (JENWAY-6800UV/VIS) spectrophotometer at 630nm, and 880nm (APHA, 1995) before the treatment process.

\section{Experimental applications}

The pre-sterilized wastewater sample was divided into 10 flasks (about $250 \mathrm{ml}$ for each) then inoculated with a young culture of the selected actinomycete isolates. The flasks were shaking in incubator at $30^{\circ} \mathrm{C}$ for 7 days. After incubation, $100 \mathrm{ml}$ of each cultured sample was filtered through bacterial filter paper then the filtrates were taken for measuring the physicochemical parameters (dissolved oxygen, TDS, salinity and $\mathrm{pH}$ ) and the nutrient salts; ammonia and orthophosphate. The percentage of nutrients removal was calculated according to the equation:

$$
\text { Removal Efficiency }(\%)=\frac{(\text { Initial concentration }- \text { Final concentration) }}{\text { (Initial concentration) }} \times 100
$$

\section{RESULTS ANDDISCUSSION}

The selected marine actinomycetes isolates were distinguished by their differential morphological and chemical characteristics (Table 1). The substrate mycelium color of four isolates of them was white, three isolates were creamy color, 
two isolates were grey and the last one was brown color and the most of them have grey to white aerial mycelia. The majority of isolates is producing beige diffusible pigments and only one produces violet pigment. The isolates were growing under the conditions; $25-38^{\circ} \mathrm{C}$ and $\mathrm{pH} 7-9$. Starch and glycerol were utilized by all isolates as carbon sources, the majority utilized lactose, dextrose, maltose and D-glucose. All the used isolates were growing in presence of $6 \% \mathrm{NaCl}$, three isolates grew in presence of $9 \% \mathrm{NaCl}$ and three isolates grew in presence of $10 \% \mathrm{NaCl}$.

Table 1: Phenotypic characteristics of actinomycetes isolates under investigation

\begin{tabular}{|c|c|c|c|c|c|c|c|c|c|c|}
\hline \multirow{2}{*}{ Character } & \multicolumn{10}{|c|}{ Isolates } \\
\hline & M5 & M 8 & M 9 & M 13 & M 15 & M 23 & M 38 & M 50 & MN & MP \\
\hline \multicolumn{11}{|l|}{ Substrate mycelium } \\
\hline Grey & + & - & + & - & - & - & - & - & - & - \\
\hline Brown & - & - & - & - & + & - & - & - & - & - \\
\hline Cream & - & + & - & + & - & - & - & - & + & - \\
\hline Beige & - & - & - & - & - & - & - & - & - & - \\
\hline White & - & - & - & - & - & + & + & + & - & + \\
\hline \multicolumn{11}{|l|}{ Aerial mycelium } \\
\hline Yellow & - & + & & & & & & & & \\
\hline White & - & - & - & - & - & - & - & - & - & - \\
\hline Cream & - & - & - & - & - & + & - & - & + & - \\
\hline Grey & + & - & + & + & - & - & + & + & - & + \\
\hline Brown & - & - & - & - & + & - & - & - & - & - \\
\hline \multicolumn{11}{|l|}{ Diffusible pigments } \\
\hline Beige & + & + & - & + & + & - & + & + & + & - \\
\hline Violet & - & - & + & - & - & - & - & - & - & - \\
\hline \multicolumn{11}{|l|}{ Growth at $\left({ }^{\circ} \mathrm{C}\right)$} \\
\hline $25-35$ & + & + & + & + & + & + & + & + & + & + \\
\hline 38 & + & + & + & + & - & - & + & - & + & + \\
\hline 45 & - & - & - & - & - & - & - & - & - & - \\
\hline \multicolumn{11}{|l|}{ Growth at pH } \\
\hline $5-6$ & - & - & - & - & - & - & - & - & - & - \\
\hline 7 & + & - & - & + & + & + & + & + & + & + \\
\hline 8 & + & + & + & + & + & + & + & + & + & + \\
\hline 9 & - & - & - & + & + & + & + & + & + & + \\
\hline \multicolumn{11}{|l|}{ Utilization of } \\
\hline Starch & + & + & + & + & + & + & + & + & + & + \\
\hline Lactose & + & + & + & + & - & + & + & + & + & + \\
\hline Dextrose & + & + & + & + & - & + & + & + & + & + \\
\hline Maltose & + & - & + & + & + & + & + & - & + & + \\
\hline Glucose & + & + & + & + & - & + & + & + & - & - \\
\hline Glycerol & + & + & + & + & + & + & + & + & + & + \\
\hline \multicolumn{11}{|l|}{$\mathrm{NaCl}(\%)$} \\
\hline 6 & + & + & + & + & + & + & + & + & + & + \\
\hline $7-9$ & - & - & - & + & - & - & + & + & - & + \\
\hline 10 & - & - & - & + & - & - & + & + & - & - \\
\hline \multicolumn{11}{|l|}{ Biochemical tests } \\
\hline Protease & + & - & + & + & - & + & - & + & + & + \\
\hline Lipase & + & + & - & + & + & + & + & + & + & - \\
\hline Urease & + & - & - & + & - & + & - & + & + & + \\
\hline Catalase & + & + & + & + & + & + & + & + & + & + \\
\hline Chitinase & - & - & - & - & - & - & - & - & - & - \\
\hline Oxidase & - & - & - & - & - & - & - & - & - & - \\
\hline Sulphide production & - & - & - & - & - & - & - & - & - & - \\
\hline Melanin production & - & - & - & - & - & - & - & - & - & - \\
\hline \multicolumn{11}{|l|}{ Degradation of } \\
\hline Cellulose & + & + & + & + & + & + & + & + & + & + \\
\hline Gelatin & - & - & - & - & - & - & - & - & - & - \\
\hline
\end{tabular}

Actinomycete numbers and kinds vary with environmental circumstances such as geographical area, $\mathrm{pH}$, temperature, humidity, nutrients and climate (Hong et al. 2009 and Arifuzzaman et al. 2010). Rifaat (2003) it has been indicated that 
actinomycetes are commonly distributed in different water bodies and attached as biofilms to any difficult substrate where they play a major part in the carbon cycle owing to their capacity to grow at low carbon content and degrade the remaining organic matter. All the cultured isolates were produced catalase, meanwhile the majority were also produced lipase and urease. Six isolates were produced protease and only one produced chitinase and oxidase. No precipitated sulphite and melanin were detected. Cellulose was hydrolyzed but no gelatin liquefaction occurred.

The BOX-PCR method can be a useful identifying material for isolates in collection with a extensive database or 16S rRNA gene sequencing and phylogenetic analysis. The amplification of bacterial genomic DNA as a biotechnological instrument plays a significant role in isolating improvements in a variety of pharmaceutical and production applications, including antibiotic biosynthesis, bioconversion and poisonous compound devolution (Li et al. 2017). Phenotypic characterization and molecular phylogenetic analysis recognized the actinomycete isolates used for treatment of wastewater. The actinomycetes isolate genomic DNA was prepared and the 16S rRNA gene coding was partly amplified using the universal primers (16S 27F and 16S 1492R), (5'AGAGTTTGCTGCTGCAG-3' and 5'GGTTACCTTGACTGACTT-3'). The sequencing data utilizing of the strategy (ABI 3730xl) was 1500 base pair. Sequencing data were aligned against the 16S rRNA sequences of (http://blast.ncbi.nlm.nih.gov/Blast.cgi). The amplicons produced by the actinomycetes isolates were identified using electrophoresis of agarose gel as shown in (Figure 1). These sequences were compared with those gave the high esthomology using Blast Search Computer Based Program and the results reported in (Table 2). The ten actinomycete isolates were then tested for biological treatment and the removal of ammonia and orthophosphate from the raw wastewater.

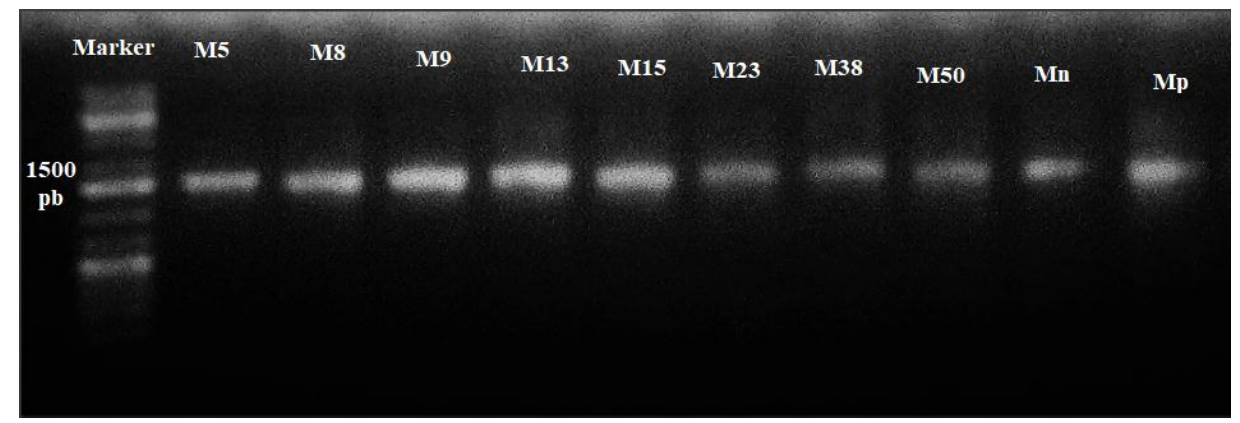

Fig. 1: Agarose gel electrophoreses of the amplified 16S rRNA gene of the actinomycetes isolates

Table 2: The similarity percentages of the most related actinomycetes species

\begin{tabular}{ccc}
\hline $\begin{array}{c}\text { Actinomycetes } \\
\text { isolates no. }\end{array}$ & Most related Species & Similarity (\%) \\
\hline M 5 & Kocuriapalustris strain TH126 & 95 \\
M 8 & Streptomyces parvus strain J59 & 96 \\
M 9 & Streptomyces griseorubens strain 173477 & 96 \\
M 13 & Streptomyces rochei strain R1-2A/D104 & 99 \\
M 15 & Streptomyces albidoflavus strain DT-A40 & 98 \\
M 23 & Streptomyces sp. strain L116 & 99 \\
M 38 & Streptomyces sp. strain A300Ydz-QZ & 91 \\
M 50 & Streptomyces sp. Strain I08A-00376 & 95 \\
MN & Streptomyces griseus strain SYA.E50 & 99 \\
Mp & Streptomyces sp. strain 66P31-1 & 99 \\
\hline
\end{tabular}




\section{Capabilities of the actinomycete strains for wastewater treatment}

The physico-chemical parameters of the raw sewage are as follows: dark brown color, with un-acceptable odors, alkaline ( $\mathrm{pH}$ 9.32) and depleted dissolved oxygen content $(0.6 \mathrm{mg} / \mathrm{l})$. The measured total dissolved salts (TDS) and salinity (\%o) recorded $1508 \mathrm{mg} / \mathrm{l}$ and $1.17 \%$ respectively. The nutrient salts of raw wastewater before bacterial treatment showed significantly high contents for ammonia and orthophosphate; 139.55 , and $22.38 \mathrm{mg} / \mathrm{l}$ respectively (Table 3 ).

Table 3: physicochemical parameters of raw wastewater before the biological treatment

\begin{tabular}{cc}
\hline Parameter & Concentration \\
\hline color & Dark brown \\
odor & Un acceptable \\
pH & 9.32 \\
TDS & $1508 \mathrm{mg} / 1$ \\
Salinity & $1.17 \%$ \\
D.O & $0.6 \mathrm{mg} / 1$ \\
Ammonia & $139.55 \pm 9.31 \mathrm{mg} / 1$ \\
Phosphate & $22.38 \pm 0.53 \mathrm{mg} / \mathrm{l}$ \\
\hline
\end{tabular}

Wastewater with high organic load causes many ecological problems (Manh, 2008). It shows adverse effects on both flora and fauna; its discharge to the land alters physical and chemical properties of the soil, thus reducing the fertility of land for crop production and its discharge to the water bodies may results in eutrophication, affecting the aquatic life and making water unfit for drinking (Manu et al. 2011). Hence, in recent years, the biological treatment system has become popular, more efficient with low cost in waste treatment (Vishakha et al. 2013).

Dissolved oxygen is considered an important pollution indicator parameter to examine the water quality. After treatment and as shown in Table (3), a slight increasing in dissolved oxygen ranging from $0.7 \pm 0$ to $0.967 \pm 0.289 \mathrm{mg} / \mathrm{l}$ was observed with isolates M8, M9, M13, M15, M23 and M38, while MP, M50, MN and M5 isolates recorded significant high increasing in the dissolved oxygen $(4.233 \pm 0.289$, $3.33 \pm 0.702,2.3 \pm 0.1$ and $1.967 \pm 0.153 \mathrm{mg} / \mathrm{l}$, respectively. The recorded high dissolved oxygen mean that there is plenty of organic matter present that provided energy for some actinomycete organisms (MP, M50, MN and M5) and they have ability to make biodegradation to most of the organic compounds, meanwhile the other actinomycetes isolates haven't this ability.

The recorded alkaline value ( $\mathrm{pH} 9.32$ ) in the raw wastewater indicated that the actinomycetes have the ability to survive under the elevated $\mathrm{pH}$ conditions. It is known that actinomycetes grow well and survive in neutral and slightly alkaline media (Trenozhnikova and Azizan, 2018). During the period of the experiment, $\mathrm{pH}$ values at all the cultured isolates were significantly declined from 9.32 to 8.283.

It is very important to be existed a sufficient alkalinity in the wastewater to balance the acid produced by bacterial nitrification process, where alterations in $\mathrm{pH}$ could have an adverse effect on nitrification. About $7.14 \mathrm{mg}$ of alkalinity (as $\mathrm{CaCO} 3$ ) are consumed to oxidize mg NHg-N. (Sedlak, 1991). This consumption of alkalinity throughout nitrification is responsible for the depressing effect on the $\mathrm{pH}$ value.

In the same manner, slight decreasing in the total dissolved salts (TDS) was observed in the used wastewater flasks during the period of the experiment. The TDS removal efficiency of the experimented species was ranged from 6.6 to $9.6 \%$ for all isolates. This would be explained by the consuming these salts by experimented 
isolates which used them as source of nourishment. Andriambeloson et al. (2017) were succeeded to decrease the TDS from wastewater collected from oilfield using the actinomycetes strains; Streptomyces albidoflavus DSM40455T and Streptomyces antibioticus NBRC12838T. Shruthi et al. (2012) found $68.8 \%$ reduction in TDS using Pseudomonas sp. in rubber processing. Gaikwad et al. (2014) recorded maximum decrease in TDS (74.36\%) using microbial consortia of different bacterial strains; Pseudomonas, Actinomycetes, Bacillus, Staphylococcus and Streptomyces.

Autotrophic and heterotrophic bacteria can remove ammonia through two processes; nitrification that converting ammonia to nitrite and nitrate in two sequential steps and de-nitrification. These bacteria can tolerate nitrogen and organic carbon loads (Joo et al. 2005). The Thiobacillus denitrificans autotrophic organism and the heterotrophic organisms Micrococcus denitrificans, Preudomonas and Archomobacter are accountable for this phase. (Torrento et al. 2010 and Kim et al. 2008).

Nitrification takes place in two phases: first, ammonia is converted to nitrite by ammonia oxidizing bacteria and this nitrite is converted to nitrate by nitrite oxidizing bacteria and actinomycetes isolates use ammonia or nitrite as an electron-acceptor and carbon dioxide as a source of carbon (Laanbroek et al. 2002). The de-nitrification librates $\mathrm{N}_{2}$ gas from nitrates. Some microorganisms can transform nitrate into nitrous oxide and nitrogen gas under anaerobic conditions through a method called denitrification that results in a net loss of nitrogen from the soil. Recent progress in identifying heterotrophic ammonia remediation bacteria has revolutionized ammonia extraction techniques for sewage treatment procedures. Bacteria obtain their source of elemental nitrogen through the assimilation of ammonia, but can also use nitrites and nitrates as well as gaseous nitrogen under certain conditions. Microorganism assimilation of ammonia is regarded one of the significant measures to remove ammonia from the manure treatment systems. The metabolism of actinomycetes has been observed as a notable source of enzymes and bioactive products and therefore an significant problem is the function of actinomycetes with respect to the removal of ammonia during the composting process. (Sasaki et al. 2005).

Table (3) shows the capacity of the chosen actinomycete isolates for ammonia removal from wastewater samples. The efficiency of the selected isolates in ammonia removal was varied obviously. The ammonia removal efficiency was ranged between 23.96 and $77.35 \%$. The highest removal of ammonia is achieved by isolate M9 followed by isolates M15 and M23 with the removal efficiencies of; 77.35\%, 67.03\% and $62.58 \%$ respectively). On the other hand, isolates M5 and M8 recorded the lowest removal efficiencies of ammonia (29.77 and $23.96 \%$ ).

By assimilating soluble orthophosphate (PO4), bacteria obtain their source of elemental phosphorus. Phosphorus ion is the final breakdown of the organic phosphorus process and is the most easily accessible type of phosphorus for biological uses. (Ahemad et al. 2009). Throughout the period of the experiment, the concentration of orthophosphate was decreased from $22.38 \pm 0.54$ to $7.00 \pm 0.00 \mathrm{mg} / \mathrm{l}$ with removal efficiencies ranging from $58.86 \%$ to $79.02 \%$. The isolates; M5, M13, M38, MN and MP recorded orthophosphate removal efficiency more than 70\%, while the rest isolates achieved removal efficiency exceeded 63\% except isolate M50 which recorded $58.86 \%$ removal efficiency. This could be because of the differential abilities of these isolates to produce acids and enzymes that responsible for breakdown the orthophosphate compounds (De Souza et al. 2000 and Seshadri et al. 2002). 
Table 4: Physicochemical parameters of wastewater after the treatment using the selected actinomycetes strains

\begin{tabular}{lllll}
\hline Bacterial name & \multicolumn{1}{c}{$\mathbf{p H}$} & \multicolumn{1}{c}{ D.O } & \multicolumn{1}{c}{ TDS } & \multicolumn{1}{c}{ Salinity } \\
\hline IS/5 & $8.603 \pm 0.025$ & $1.967 \pm 0.153$ & $1408.33 \pm 27.06$ & $1.093 \pm 0.020$ \\
IS/8 & $8.5 \pm 0.052$ & $0.767 \pm 0.058$ & 138.6 & 1.086 \\
IS/9 & $8.477 \pm 0.032$ & $0.7 \pm 0$ & $1391 \pm 39.53$ & $1.08 \pm 0.03$ \\
IS/13 & $8.48 \pm 0.046$ & $0.7 \pm 0$ & $1362.83 \pm 32.06$ & $1.06 \pm 0.02$ \\
IS/15 & $8.507 \pm 0.047$ & $0.7 \pm 0$ & $1375.16 \pm 11.02$ & $1.07 \pm 0.01$ \\
IS/23 & $8.453 \pm 0.032$ & $0.7 \pm 0$ & $1378 \pm 28.33$ & $1.07 \pm 0.02$ \\
Is/38 & $8.42 \pm 0.026$ & $0.967 \pm 0.289$ & $1384.5 \pm 6.5$ & $1.076 \pm 0.005$ \\
IS/50 & $8.443 \pm 0.032$ & $3.333 \pm 0.702$ & $1391 \pm 6.5$ & $1.083 \pm 0.005$ \\
IS/MN & $8.377 \pm 0.067$ & $2.3 \pm 0.1$ & $1388.83 \pm 3.75$ & $1.08 \pm 0$ \\
IS/NP & $8.283 \pm 0.064$ & $4.233 \pm 0.289$ & $1369.16 \pm 44.52$ & $1.036 \pm 0.037$ \\
\hline
\end{tabular}

Table 5: Removal percentage (\%) of nutrients (ammonia and orthophosphate) in wastewaters after treatment using actinomycetes strains

\begin{tabular}{lcccc}
\hline $\begin{array}{c}\text { Bacterial } \\
\text { strains }\end{array}$ & $\begin{array}{c}\text { Ammonia } \\
\text { removal } \\
(\%)\end{array}$ & $\begin{array}{c}\text { Ammonia } \\
\text { removal } \\
(\mathbf{m g} / \mathbf{L})\end{array}$ & $\begin{array}{c}\text { orthophosphate } \\
\text { removal } \\
(\%)\end{array}$ & $\begin{array}{c}\text { Phosphate } \\
\text { removal } \\
(\mathbf{m g} / \mathbf{L})\end{array}$ \\
\hline IS/5 & 29.77 & 41.55 & 72.04 & 24.05 \\
IS/8 & 23.96 & 33.44 & 63.45 & 21.18 \\
IS/9 & 77.35 & 107.95 & 64.94 & 21.68 \\
IS/13 & 59.37 & 82.85 & 73.30 & 24.47 \\
IS/15 & 67.03 & 93.54 & 68.99 & 23.03 \\
IS/23 & 62.58 & 87.33 & 68.82 & 22.974 \\
IS/38 & 46.96 & 65.54 & 70.24 & 23.447 \\
IS/50 & 47.39 & 66.14 & 58.86 & 19.65 \\
IS/MN & 33.63 & 46.94 & 79.02 & 26.38 \\
IS/NP & 55.83 & 77.91 & 76.73 & 25.6134 \\
\hline
\end{tabular}

\section{CONCLUSION}

Wastewater treatment is one of the extreme problems for both developed and developing countries. Addendum for that, globalization placing defy for waste management within communities. Wastewater treatment is very essential to achieve sustainable expansion in economic issues, health concerns, and environmental problems and the role of microorganisms in wastewater treatment helps to treat and purify wastewater and make it less harmful to the environment. In this study, ten marine actinomycetes isolates were isolated from Suez gulf, Egypt using for biological treatment to samples of raw sewage. All of isolates have ability to treatment of domestic wastewater in an acceptable manner especially strains Streptomyces griseorubens and Streptomyces griseus.

\section{REFERENCES}

Ahmed, M. Zaidi; A., Khan, M.; and Oves, M. (2009). Biological importance of phosphorus and phosphate solubilizing microorganisms - an overview. Phosphate solubilizing microbes for crop improvement. Nova, New York, 1-4

Akond, M. A.; Jahan, M. N.; Sultana, N. and Rahman, F. (2016). Effect of Temperature, $\mathrm{pH}$ and $\mathrm{NaCl}$ on the Isolates of Actinomycetes from Straw and Compost Samples from Savar, Dhaka, Bangladesh. American Journal of Microbiology and Immunology, 1(2): 10-15.

Andriambeloson, O.; Rabenirina, H.; Rajoelisoa, A.; Ramaroson, L. and Rasolomampianina, R. (2017). Purifying potential of Streptomyces albidoflavus 
strain DSM 40455T and Streptomyces antibiotics strain NBRC 12838T in wastewater treatment. American Journal of Water Resources, 5(4): 117-124.

Arifuzzaman, M.; Khatun, M. R. and Rahman, H. (2010). Isolation and screening of actinomycetes from sundarbans soil for antibacterial activity. Afr. J. Biotechnol., 9: 4615-4619.

Association, A. P. H. (1995). Water Environment Federation. Standard methods for the examination of water and wastewater, 22.

Bensultana, A.; Ouhdouch, Y.; Hassani, L.; Mezrioui, N.E. and Rafouk, L. (2010). Isolation and characterization of wastewater sand filter actinomycetes. World Journal of Microb. and Biot., 26(3): 481-487.

Davenport, R.J.; Curtis, T.P.; Goodfellow, M.; Stainsby, F.M. and Bingley, M. (2000). Quantitative use of fluorescent in situ hybridization to examine relationships between mycolic acid-containing actinomycetes and foaming in activated sludge plants. Appl. Environ. Microbiol., 66(3): 1158-1166. https://doi.org/10.1128/AEM. 66.3.1158-1166.2000

De Souza, B.D.; Nair, S. and Chandramohan, D. (2000). Phosphate solubilizing bacteria around Indian peninsula. Indian J. Mar. Sci., 29: 48-51.

Gaikwad, G.L.; Wate, S.R.; Ramteke, D.S. and Roychoudhury, K. (2014). Development of microbial consortia for the effective treatment of complex wastewater. J. Bioremed. Biodeg., 5: 1-6.

Heard, J.; Harvey, E.; Johnson, B.B.; Wells, J.D. and Angove, M.J. (2008). The effect of filamentous bacteria on foam production and stability. Colloids and surfaces B: Biointerfaces, 63(1): 21-26. https://doi.org/10.1016/j.colsurfb. 2007.10.011

Henze, M. (1996). Biological phosphorus removal from wastewater: processes and technology. Water Quality International, 32-36.

Hong, K.; Gao, A.; Xie, Q.; Gao, H.; Zhuang, L.; Lin, H.; Ya, H.; Li, J.; Yao, X.; Goodfellow, M. and Ruan, J. (2009). Actinomycetes for marine drug discovery isolated from mangrove soils and plants in China. Mar. Drugs, 7(1): 22-44.

Joo, H. S.; Hirai, M. and Shoda, M. (2005). Nitrification and denitrification in high strength ammonium by Alcaligenes feacalis. Biotechnology Letters, 27(11): 773-778.

Khardenavis, A.A.; Kapley, A. and Purohit, H.J. (2007). Simultaneous nitrification and denitrification by diverse Diaphorobacter sp. Applied Microbiology and Biotechnology, 77(2): 403-9. https://doi.org/10.1007/s00253-007-1176-5

Khin,T. and Annachhatre, A.P. (2004). Novel microbial nitrogen removal processes. Biotechnology Advances, 22(7):519-532.

Kim, M.; Jeong, S.Y.; Yoon, S.J.; Cho, S.J.; Kim, Y.H.; Kim, M.J.; Ryu E.Y. and Lee, S.J. (2008). Aerobic denitrification of Pseudomonas putida AD-21 at different $\mathrm{C} / \mathrm{N}$ ratios. Journal of Bioscience and Bioengineering, 106(5): 498502.

Laanbroek, H.J.; Bär-Gilissen, M.J. and Hoogveld, H. L. (2002). Nitrite as a stimulus for ammonia-starved Nitrosomonas europaea. Appl. Environ. Microbiol, 68(3): 1454-1457.

Lee, N.; Nielsen, P.H.; Aspegren, H.; Henze, M., Schleifer, K.H. and CourJansen, J. (2003). Long-term population dynamics sludge and in situ physiology in activated systems with enhance and without biological phosphorus removal operated with nitrogen removal. Syst. Appl. Microbiol, 26: 211-227.

Lemmer, H. (1986). The ecology of scum causing Actinomycetes in sewage treatment plants. Water Research, 20(4): 531-535. https://doi.org/10.1016/00431354 (86)90204-6 
Lemmer, H. and Kroppensted, R. M. (1984). Chemotaxonomy and Physiology of Some Actinomycetes Isolated from Scumming Activated Sludge. Syst. and Appl. Microbiol., 5(1): 124-135. https://doi.org/10.1016/S0723-2020 (84)80057-0

Lemmer, H. and Baumann M. (1988). Scum actinomycetes in sewage treatment plants-Part 2. Water Research, 22(6): 761-763. https://doi.org/10.1016/00431354 (88)90187-X

Li, L.; Zheng, G.; Chen, J.; Ge, M.; Jiang, W. and Lu, Y. (2017). Multiplexed sitespecific genome engineering for overproducing bioactive secondary metabolites in actinomycetes. Metabolic engineering, 40: 80-92.

Li, Q.; Chen, X.; Jiang, Y.; and Jiang, C. (2016). Morphological identification of actinobacteria Actinobacteria-Basics and Biotechnological Applications. IntechOpen.|DOI: 10.5772/61461

Madoni, P.; Davoli, D.; and Gibin, G. (2000). Survey of filamentous microorganisms from bulking and foaming activated-sludge plants in Italy. Water Res., 34: 1767-1772. https://doi.org/10.1016/S0043-1354 (99)00352-8

Manh, D. (2008). Bioremediation of vegetable oil and grease from pollute wastewater in dairy factory. J. Sci. Nat. Sci. Technol., 24: 56-62.

Manu, K.J.; Mohana,V.S. and Ganeshaiah, K.N. (2011). Effluent generation by the dairy units: characterization and amelioration for irrigation. Int. J. Res. Chem. Environ., 1: 173-182.

Metcalf and Eddy (1991). Wastewater Engineering. Treatment, Disposal, Reuse. 3rd edition, McGraw-Hill Int. Ed., Singapore.

Mohanraj, G. and Sekar, T. (2013). Isolation and screening of actinomycetes from marine sediments for their potential to produce antimicrobials. Int $\mathbf{J}$ Life Sci Pharma Res., 2(12): 115-126.

Mulder, J.W. and Rensink, J.H. (1987). Introduction of biological phosphorus removal to an activated sludge plant with practical limitations, Biological Phosphate Removal from Wastewaters. In Advances in Water Pollution Control, R.Ramadori Ed., Pergamon, England, 213-223.

Norouzi, H.; Danesh, A.; Mohseni, M. and Khorasgani, M. R. (2018). Marine Actinomycetes with Probiotic Potential and Bioactivity against Multidrugresistant Bacteria. International journal of molecular and cellular medicine, 7(1): 44.

Qin, Y.; Jiandong, W.u. and Hai, Ouyang (2013). The Application of Organica Ecological Technology in Residential Sewage Treatment. Journal of Environmental Protection, 04(01): 31-34. https://doi.org/10.4236/jep .2013.41B006

Rifaat, H. M. (2003). The biodiversity of actinomycetes in the River Nile exhibiting antifungal activity. J. Med. Ecolo., 4(3): 5-7.

Sasaki, H.; Yano, H.; Sasaki, T. and Nakai, Y. (2005). A survey of ammoniaassimilating micro-organisms in cattle manure composting. Journal of applied microbiology, 99(6): 1356-1363.

Sedlak, R.I. (1991). Phosphorus and Nitrogen Removal from Municipal Wastewater: Principles and Practice, 2nd Ed. The Soap and Detergent Association, NY, USA, pp. 3-41. ISBN: 9780873716833. https://doi.org/ $10.1201 / 9780203743546$

Seshadri, S.; Ignacimuthu, S. and C. Lakshminarsimhan (2002).Variation in heterotrophic and phosphate solubilizing bacteria from Chennai, southeast coast of India. Indian J. Mar. Sci., 31: 69-72. 
Shrivastava, P.; Kumar, R.; Yandigeri, M. S.; Malviya, N. and Arora, D. K. (2015). Isolation and characterization of Streptomycetes with plant growth promoting potential from Mangrove ecosystem. Polish journal of microbiology, 64(4): 339-349.

Shruthi, S.; Raghavendra, M. P.; Swarna Smitha, H.S. and Girish, K. (2012). Bioremediation of rubber processing industry effluent by Pseudomonas sp. Int. J. Res. Environ. Sci. Tech., 2: 27-30.

Torrento, C.; Cama, J.; Urmeneta, J.; Otero, N. and Soler, A. (2010). Denitrification of groundwater with pyrite and Thiobacillus denitrificans. Chemical Geology, 278(1-2): 80-91. https://doi.org/10.1016/j.chemgeo.2010.09.003

Trenozhnikova, L. and Azizan, A. (2018). Discovery of Actinomycetes from Extreme Environments with Potential to Produce Novel Antibiotics. Central Asian Journal of Global Health, 7(1).

Vishakha, S. S.; Kulkarni, S.W. and Minal W. (2013). Physicochemical characterization of dairy effluents. Int. J. Life Sc. Bt. Pharm. Res., 2: 2250-3137.

Wenzel, M.C. and Ekama, G.A. (1997). Principles in the design of single sludge activated sludge systems for biological removal of carbon, nitrogen and phosphorus. In La dephosphatation des eaux usees, Ed. CEBEDOC, Belgium, 13-26.

Yu, J.; Zhang, L.; Liu, Q.; Qi, X.; Ji, Y. and Kim, B. S. (2015). Isolation and characterization of actinobacteria from Yalujiang coastal wetland, North China. Asian Pacific Journal of Tropical Biomedicine, 5(7): 555-560. 